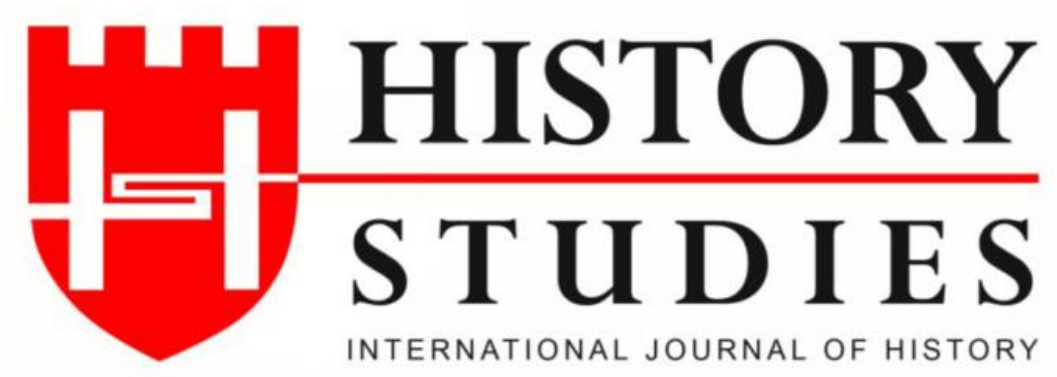

ISSN: 13094173 (Online) 1309 - 4688 (Print)

Volume 12 Issue 3, June 2020

DOI Number: 10.9737/hist.2020.862

Araştırma Makalesi

Makalenin Geliş Tarihi: 18.02.2020 Kabul Tarihi: 21.05.2020

Atıf Künyesi: Gökçe Yoğurtçu - Yunus Emre Gürbüz, “Kırgız Halkının Gözünden Gorbaçov: Bir

Sözlü Tarih Çalışması", History Studies, 12/3, Haziran 2020, s. 961-979.

\title{
Kırgız Halkının Gözünden Gorbaçov: Bir Sözlü Tarih Çalışması
}

\author{
Gorbachev through the Eyes of the Kyrgyz People: A Study of Oral History
}

\author{
Dr. Gökçe Yoğurtçu - Doç. Dr. Yunus Emre Gürbüz \\ ORCID No: 0000-0002-2404-3908 / 0000-0003-4701-6571 \\ Kırgızistan Türkiye Manas Üniversitesi
}

Öz: Mihail Gorbaçov 1986'da Sovyet Sosyalist Cumhuriyetler Birliği'nde (SSCB) glasnost (açılık) ve perestroyka (yeniden yapılanma) girişimlerini başlatmış; Birliğin daha etkin ve verimli hale gelmesi için büyük umutlarla radikal adımlar atılmışır. Gorbaçov'un reformları dünyada geniş ilgi toplamış, kendisine yaygın bir popülerlik kazandırmıştır. Görev süresi sona erdikten sonra da Gorbaçov Türkiye dâhil SSCB sonrası ülkeler dışında uzun yıllar SSCB tarihinin en önemli simalarından biri olarak tanınmıştır. Gorbaçov'un başlattığı reformlar yöneticilerin beklemediği bir şekilde ülkenin dağılmasına ve hatta SSCB'nin sona ermesine yol açmıştır. Bu olaylar silsilesi içinde Kırgızistan 31 Ağustos 1991'de bağımsızlığına kavuşmuştur.

Bu çalışmada istemeden de olsa Kırgızistan'ın bağımsızlığına giden yolu açan Gorbaçov'un Kırgızistan'da nasıl görüldüğünün ortaya konulması amaçlanmaktadır. Bunun için hayatının önemli bir kısmını SSCB'de yaşamış, 1991'de elli yaşın üstünde olan 48 kişiyle sözlü tarih çalışması gerçekleştirilmiştir. Çalışmanın bulguları, Gorbaçov'un bu kuşak tarafından Kırgızistan'ın bağımsızlık yolunu açan kişi olarak saygı görmesi yerine, SSCB'nin yıkılışındaki rolü nedeniyle son derece olumsuz bir şekilde algılandığını göstermektedir.

Anahtar Kelimeler: Glasnost, Kırgızistan, Mihail Gorbaçov, Perestroyka, Sözlü Tarih.

Abstract: Mikhail Gorbachev initiated reforms called glasnost and perestroika in the USSR, in 1986, and made radical steps with great hopes in order to enhance the efficiency and productivity of the Union. Gorbachev's reforms were greeted with enthusiasm in the world, and he obtained an immense popularity. Even after his presidency his popularity remained as one of the most celebrated historical figures of the USSR outside of the post-USSR countries - including Turkey - for long years. The reforms introduced by Gorbachev resulted in the dissolution of the Union and even in the termination of the USSR as an unintended consequence for the rulers. Thus Kyrgyzstan acquired its independence.

This study aims to present, how in Kyrgyzstan Gorbachev is being perceived, who unintentionally opened the road to its independence. The data has been collected through a study of oral history conducted with 48 correspondents over 50 years of age during the independence and had lived in the USSR. The data demonstrated that vast majority of this generation perceives Gorbachev very negatively because of his role in the dissolution of the USSR, instead of respecting him as a person, who had enabled Kyrgyzstan's independence.

Keywords: Glasnost, Kyrgyzstan, Mikhail Gorbachev, Perestroika, Oral History.

\footnotetext{
* Bu makale, 15-17 Kasım 2019 tarihleri arasında düzenlenen II. Uluslararası Türk-Rus Dünyası Akademik Araştırmalar Kongresi'nde (Ankara) sunulmuş ve sadece özeti yayınlanmış bildirinin genişletilmiş ve yeniden düzenlenmiş şeklidir.
} 


\section{Giriş}

Bu makalede 1985-1991 yılları arasında Sovyet Sosyalist Cumhuriyetler Birliği'ni (SSCB) yöneten Mihail Gorbaçov'un Kırgızistan'da nasıl hatırlandığg ortaya konulmaya çalışılacaktır. Bilindiği üzere Gorbaçov, SSCB'de reform yapma girişiminde bulunmuş, ancak atılan adımlar tersine SSCB'nin dağılmasıyla sonuçlanmıştır. Böylelikle Gorbaçov SSCB'nin son yöneticisi olarak tarihte yerini alırken, istemeden Kırgızistan dâhil 15 bağımsız cumhuriyetin doğmasının yolunu açmıştır.

Türkiye'nin de dâhil olduğu Batı ülkeleri arasında Gorbaçov, Doğu Bloku (Varşova Paktı) ülkelerinin Birlik'ten ayrılması, ardından SSCB'yi oluşturan cumhuriyetlerin bağımsız kalmasını kan dökülmeden izlediği için popüler biridir. Gorbaçov'un popülerliği henüz SSCB'nin başında olduğu yıllarda, başlattığı reformlar ve Soğuk Savaşın yarattığı nükleer tehdit korkusunu azaltan barışçıl politikasıyla başlamış, aradan geçen zamanda azalsa da tamamen kaybolmamıştır.

Sözlü Tarih araştırmaları Kırgızistan gibi Sovyet sonrası cumhuriyetlerde yaşananları belgelemek için vazgeçilmez öneme sahiptir. SSCB dönemi arşiv belgelerinde ayrıntılı bilgilere erişmek mümkün olsa da, insanların neler yaşadığı hakkındaki veriler yetersiz kalmaktadır. Soğuk Savaş döneminde gerek SSCB içinde gerekse dişında propaganda amaciyla üretilmiş birçok bilgi bulunduğundan bunların ötesine geçip, insanların bilgisine ve yaşanmışlıklarına ulaşmak için sözlü tarih çalışmaları bu coğrafya için özel bir yere sahip olmaktadır. ${ }^{1}$

SSCB'nin dağılması sırasında bağımsızlığını kazanan cumhuriyetlerden Kırgızistan'da ise, halkın genel olarak Gorbaçov'a olumsuz baktığının gözlemlenmesi neticesinde, konunun incelenmesi ve olumsuz bakışların gerekçelerinin tespit edilmesi gereksinimi doğmuştur. $\mathrm{Bu}$ konuyla ilgili veriler, 2007 yılında Kırgızistan'ın tüm bölgelerinde ve büyük şehirlerinde (Bişkek, Calal Abad, Çüy, Isık Göl, Narın, Oş, Talas) gerçekleştirilen ve altmış beş yaş üstü 48

\footnotetext{
${ }^{1}$ SSCB dağıldıktan sonra özellikle Rusya üstüne sözlü tarih çalışmaları yapılmıştır. Türkçe yayımlanan bir örnek için bkz. Orlando Figes, Karanlıkta Fısıldaşanlar, Stalin Rusya'sında Özel Yaşam, çev. Nurettin Elhüseyni, YKY, İstanbul 2011.

Kırgızistan ve Özbekistan üstüne Japonya'da çalışan Özbekistan asıllı Timur Dadabayev sözlü tarihe dayalı saha çalışmalarının sonuçlarını çeşitli makalelerinde paylaşmıştır. Örneğin bkz. Timur Dadabaev \& Hisao Komatsu (ed.), Kazakhstan, Kyrgyzstan, and Uzbekistan: Life and Politics during the Soviet Era, Palgrave Macmillan, Londra 2017; Timur Dadabaev, Kiokuno Nakano Soren: Chyuou Ajia no Hitobito ga Ikita Shyakaisyugi Jidai (Soviet Union Remembered: Everyday Life Experiences of Socialist Era in Central Asia), Tsukuba University Press, Tokyo 2010; Timur Dadabaev, "Power, Social Life, and Public Memory in Uzbekistan and Kyrgyzstan," Inner Asia, C.12, S.1, 2010, s. 25-48; Timur Dadabaev, Identity and Memory in Post-Soviet Central Asia: Uzbekistan's Soviet Past, Routledge, London 2016.

Akademik kariyerini ABD'de sürdüren Türkiye asıllı Ali İğmen de arşiv belgeleri ve sözlü tarih yöntemiyle Kırgızistan'daki Sovyet Kültür Dernekleri üstüne kapsamlı bir çalışma yayımlamıştır. Bkz. Ali İğmen, Speaking Soviet with an Accent: Culture and Power in Kyrgyzstan, University of Pittsburgh Press, Pittsburgh 2012.

Ayrıca Guljanat Kurmangaliyeva Ercilasun da Kırgızistan üstüne projeler çerçevesinde gerçekleştirilmiş saha çalışmalarına dayanarak yayınlar yapmıştır. Bkz. Güljanat K. Ercilasun, "Remembered Tradititons and Lifestyles of Soviet Kyrgyzstan", Inner Asia, C.12, S.1, 2010, s. 157-175; Güljanat K. Ercilasun, "Famines in Kyrgyzstan: The Memories of the 1930s and 1940s", The Journal of Central Asian Studies, Keşmir Üniversitesi, C.18, S.1., SrinagarHindistan 2009, s. 63-73; Güljanat K. Ercilasun, "Enrichment of Knowledge Through Memory Studies: Oral History Research Projects in Kyrgyzstan", SangSaeng: The Journal of UNESCO Asia-Pacific Centre of Education for International Understanding (APCEIU), 2011, s.28-31; Güljanat K. Ercilasun, "Kazakistan ve Kırgızistan'da Kolektifleştirme: Sözlü Tarih Çerçevesinden Bir Bakış”, Gazi Türkiyat Türkoloji Araştırmaları, S.19, 2016, s. 11-22; Güljanat K. Ercilasun, "Famine in Kyrgyzstan in the 1930s and 1940s", Kazakhstan, Kyrgyzstan, and Uzbekistan: Life and Politics during the Soviet Era, ed. Timur Dadabaev \& Hisao Komatsu, Palgrave Macmillan, Londra 2017, s. 39-51.
} 
kişiyle yapılan Sözlü Tarih Araştırması görüşmelerinden derlenmiştir. ${ }^{2}$ Bunlar içerisinden 40 görüşmede daha önce değerlendirilmemiş, Gorbaçov ile ilgili yorumlar yer almaktadır. Bu görüşmeler, belirli temalar etrafında kategorilere ayrılarak verilerin "içerik analizi” yapılmıştır.

Bu çalışmada, öncelikle Gorbaçov dönemi hakkında bilgi verilecek, ardından Kırgızistan'da yapılan ilgili sözlü tarih çalışması verilerinden hareketle Gorbaçov dönemine nasıl bakıldığ hakkındaki değerlendirmeler sunulacaktır.

\section{Mihail Gorbaçov ve Dönemi (1985-1991)}

Mihail Gorbaçov, 1985'te SSCB'nin son lideri olarak iktidara geldiğinde önceki dönemlerden ağır sorunlar devralmış ve bunlara çözüm bulacak genç, entelektüel ve parlak bir siyasetçi olarak umut yaratmıştı. Gorbaçov'un dönemi ekonomideki tıkanma ve yaygın yolsuzluklarla mücadele için reformlarla başladı. Sistemin sorunlarının açıklıkla ortaya konulabilmesi için önce glasnost, ardından daha etkin bir işleyiş için yeniden yapılanmayı hedefleyen perestroyka ile SSCB köklü arayışlar içine girdi.

Gorbaçov, içeride uyguladığı reformlarla birlikte dış siyasette "Doğu-Batı Karşılıklı Bağımlılığı" kabulü ile Brejnev dönemi dış siyaset yaklaşımını değiştirdi, nükleer silahların azaltılması yönünde ABD ile anlaşmaya varıldı, Afganistan'dan çekilme başlatıldı. Gorbaçov'un yaptıkları, Batı'da sevinçle karşılandı, gelmiş geçmiş en popüler Sovyet lideri olarak ün kazanmasını sağladı. Gorbaçov, gerek SSCB döneminde gerekse SSCB yıkıldıktan sonra Nobel Barış Ödülü (1990) dâhil pek çok ödül aldı, Time gibi önemli dergiler defalarca onu tek başına kapak yaptı (25 Mart 1985, 9 Eylül 1985, 27 Temmuz 1987, 14 Aralık 1987, 4 Ocak 1988, 1 Ocak 1990, 19 Şubat 1990, 4 Haziran 1990, 31 Aralık 1990, 23 Aralık 1991); 1988'de Time dergisi onu "yılın adamı" (4 Ocak 1988), 1990'da ise "on yılın adamı" seçti (1

Volume 12 Issue 3 June 2020 Ocak 1990). Altı yıllık iktidarı döneminde (1985-1991) Gorbaçov yaşayan en popüler devlet adam 1 haline geldi.

SSCB yıkıldıktan sonra sahneden çekilse de, son olarak 2018'de dünyaca ünlü, bol ödüllü Alman yönetmen Werner Herzog'un çektiği "Meeting Gorbachev" (Gorbaçov ile Görüşme) belgeselinde görüldüğü gibi, Batı'da ona olan hayranlık halen varlığını korumaktadır. Herzog belgeselde "Sizi seviyoruz ve ben sizi seviyorum" sözleriyle bunu ifade etmiştir. Gorbaçov özellikle Almanya'da Berlin Duvarı'nın yıkılması ve Federal (Batı) Almanya ile Demokratik (Doğu) Almanya'nın kan dökülmeden, herhangi bir engelleme olmadan birleşmesine izin vermesi nedeniyle çok sevilmektedir ki Herzog da sevgisinin nedenini açıklarken, "çünkü yeniden birleşme benim için önemliydi" sözleriyle bunu gerekçelendirmiştir. ${ }^{3}$

SSCB dağıldıktan sonra kurulan cumhuriyetlerde ise o dönemi yaşamış kuşak arasında Gorbaçov'a bakış olumlu olmaktan çok uzaktır. Gorbaçov, iyi niyetle başlamış olsa dahi, işler kontrolden çıkmış, SSCB'nin dağılması ve sosyalizmin sona ermesiyle reformlar beklenmedik sonuçlar doğurmuştur. Sözlü tarih çalışması sırasında görüşülen bir kişinin ifade ettiği durum gibi "az binilen ata binerek, sonra idare edemeyecek hale geldiğinde kendisi küt diye yere düsser ya, aynen öyle oldu!",4

Gorbaçov'un neden Batı'da sevilirken, eski Sovyet cumhuriyetlerinde, örneğin Kırgızistan'da genelde nefretle anıldığını anlamak için öncelikle onun dönemi ve yaptıklarından söz etmek gerekiyor.

\footnotetext{
2 “20. Yüzyılda Kırgız Milli Kimliğinin Gelişim Süreci” Sözlü Tarih Araştırması, Belgesel Film Çekimi. Kırgızistan Türkiye Manas Üniversitesi, Maltepe Üniversitesi ve Türkiye İşbirliği ve Kalkınma İdaresi Başkanlığı (TIKKA) Projesi, 2007.

${ }^{3}$ Werner Herzog, André Singer, Meeting Gorbachev, A\&E Networks, New York, United States 2018.

${ }^{4}$ İşenbay Abdırazakov, Bişkek, Nisan 2007.
} 


\subsection{Gorbaçov Öncesi Siyasal İktidar ve Sorunlar}

Gorbaçov’un iktidarı öncesinde 18 yıllık Brejnev döneminin (1964-1982) ardından 15 aylık Andropov ve 13 aylık Çernenko dönemleri yaşanmıştı. Brejnev dönemi, halefi Kruşçov dönemindeki yumuşama politikalarına son verilerek, tekrar sık1 disiplinle SSCB'nin üretim artışıyla ilgili sorunları aşmaya çalıştığı bir dönem olarak yaşanmıştı. Brejnev döneminde istikrar ve üretimde sınırlı bir artış yaşanmış, ayrıca bir nükleer güç ve uzay gücü olan ülke dünyadaki iki süper güçten biri olarak uluslararası siyasetteki konumunu pekiştirmişti. Brejnev, Kruşçov'un koyduğu "yirmi yılda komünizme ulaşma" hedefi yerine daha ihtiyatlı bir "gelişmiş sosyalizm" tanımı yapmış ve gelişmenin sürdürülmesi için önceliği bilimsel ve teknolojik gelişmelere vermişti.

Fakat himayecilik (clientalism), rüşvet, yolsuzluk, alkolizm, üst düzey parti üyelerinden oluşan elit bir nomenklatura, personelin görevlerinin sabit hale getirilmesiyle Brejnev'in son yıllarının parti üyelerinin yaşlanması ve gerontokrasi (yaşlılar iktidarı) SSCB'nin biriken sorunları arasındayd $1 .{ }^{5}$ Bunlara üretimde hedeflenen artışların sağlanamaması ve stagnasyon (durgunluk) gibi sorunların eklenmesiyle, SSCB'de Brejnev sonrasındaki arayışlar için gerekli zemin oluşmuştu.

Brejnev'in 1982'deki ölümünün ardından iktidara gelen Andropov (1914-1984), ilk iş olarak ekonomiye gerekli dinamizmi kazandıracak, yolsuzlukları azaltacak reformlara girişti, Brejnev'in damadı dâhil pek çok kişi karıştıkları rüşvet ve yolsuzluklar nedeniyle tutuklandı. Ayrıca Gorbaçov ve Aliyev gibi gençleri kendi yardımcılıklarına yükselterek genç kuşağın önünü açtı. Başlattığı reformların sonucu görülemeden, kısa süren iktidarının ardından 1884 'teki ölümüyle, yerini parti gerontokrasisindeki bir başka güçlü üye, parti içindeki Andropov reformları karşıtı kanat tarafından desteklenen Çernenko (1911-1985) aldı. Kısa süren görev süresinde Çernenko, Andropov'un reform politikalarının tersine Brejnev dönemindeki katı politikalara döndü. Partinin ajitasyon-propaganda kollarından gelen biri olarak, üretim artışı için ajitasyon-propagandayı öne çıkardı. Gorbaçov'u İkinci Sekreter olarak onun halefi konumuna getirdi.

\subsection{Gorbaçov Döneminde SSCB'nin Geri Tepen Toparlanma Çabaları ve Çöküş}

Gorbaçov, 1985'te Çernenko'nun ölümünün ardından iktidara geldiğinde, partideki gerontokrasinin dişında, henüz 47 yaşında, partiye ve ülkeye dinamizm kazandıracak biri olarak selamland. ${ }^{6}$ Güler yüzlü, eğitimli, hatta Lenin'den beri üniversite eğitimi olan ilk lider olarak ülkenin biriken sorunlarını çözecek biri olarak umut vadediyordu. Çalışkan, kendini görevine adamış, gençlik çağından beri komsomol'da ("Komünist Gençlik Birliği", parti gençlik kolları), Moskova Devlet Üniversitesinde şeref derecesiyle bitirdiği Hukuk eğitiminde ve sonrasında aldığı görevlerde kendini kanıtlamış biriydi. Komsomol, üniversite ve Kuzey Kafkasya'da tanıdığ ${ }_{1}$ kişilerden bir ekip kurarak, eski kadroların yerine yeni kadrolarla ülkeye gerekli dinamizmi kazandırmak için işe girişti. Bölgelere kadar uzanan bu kadro yenileme hareketi sonucunda 1987'de Brejnev dönemi kadrolarının dörtte üçü değiştirilmişti. Güler yüzlü imajını SSCB'nin ilk first lady'si olan eşiyle halkın arasına karışması tamamlıyor ve SSCB içinde dışında popülerliğini yükseltiyordu.

Planlı ekonomi sayesinde Stalin döneminde rekor kıran bir üretim artış1 görülmüş, ancak zengin kaynaklara ve geniş topraklara sahip SSCB'de ekstansif büyümeden (yayılarak büyüme) intansif büyümeye (yoğunlaşarak büyüme) geçilememiş ve Brejnev döneminin ortalarına

${ }_{6}^{5}$ Alec Nove, Stalinism and After. The Road to Gorbachev, University of Glasgow, London 1988, s.177.

${ }^{6}$ Archie Brown, The Gorbachev Factor, Oxford University Press, Oxford 1996, s. 53. 
gelindiğinde verimlilik düşmeye başlamıştı. Gelişmiş ülkelerde GSMH artarken, SSCB'de düşmeye başlaması, gelişmiş kapitalist ülkeleri geçmek hedeflenirken, durumu daha da vahim hale getiriyordu.

Gorbaçov, Mart 1985'te iktidara gelmesinin hemen ardından öncelikle sorunların açıklıkla telaffuz edilmesi ve bunlara çözüm bulunması, vatandaşların sisteme daha çok sahip çıkabilmesi için glasnost siyasetini ilan etti. 1986 Şubatında 27. Parti Kongresinde bunu resmen açıkladı ve Kruşçov dönemindeki Stalin dönemi suçları açıklandı ve suçlananların affı Kruşçov dönemindekinin ötesine taşınd1.

\subsubsection{Perestroyka ve Ekonomik Durum}

Gorbaçov'un adıyla anılan bir diğer önemli siyaset olan perestroyka (yeniden yapılanma) da iktidarının ilk aylarında Haziran 1985 'te ilan edildi, fakat uygulamaya konması Haziran 1987'yi buldu. Durgunluğun aşılması için başlatılan bu girişimle her şeyin devlet kontrolünde olduğu "devlet sosyalizmi”"nden "piyasa sosyalizmi"ne geçilmesi hedefleniyordu ve bu da Lenin döneminde uygulanan NEP (yeni ekonomi politikası) ile meşrulaştırılıyordu. 1987 yılında Gorbaçov adına yayımlanan ve perestroykanın anlatıldığı kitabın başlığı da buna işaret etmektedir: Oktyabr i perestroyka: revolutsia prodoljaetsa (Ekim ve Perestroyka: Devrim Devam Ediyor) ${ }^{7}$. Böylelikle, kendi satın alacağı hammaddeyi, üretimi ve ürünü satacağı pazarı kendi belirleme hakkına sahip, işçi yönetimine dayalı, demokratik, mali olarak özerk fabrikaların önünün açılması ve ayrıntılı merkezi planlamanın dayattığ tıkanıklığın aşılması bekleniyordu. Tarımsal üretim de benzer şekilde serbest bırakılıyor ve öncesindeki üretim ve satış izinleri için alınması gereken imzalar kaldırılıp, bürokrasi azaltılarak, devlet kotası karşılandıktan sonra kalan ürünün istendiği gibi satışına izin veriliyordu. ${ }^{8}$

1985-1989 arasında aşamalı olarak merkezi planlama dışında ekonomi alanları yaratılmış, köylüye toprak verilmiş, özel işletmelere, hatta dış ticarete kısmi serbestlik tanınmış, pazarlara izin çıkmış, ama bunun yanında verimsiz çiftliklerin iflas etmesinin önü açılmış, devlet destekleri kaldırılmıştır.

Tüm çabalara karşın 1987-1988'de üretim sadece \% 1,5 artış göstermiş, tarımsal üretim bir önceki yılın altına düşmüş, devletin başlattığ 1 pek çok proje yarım bırakılmış, devlet gelirleri azalmıştır. Ekonomi daha da kötüye giderken, Brejnev'in belirlediği bilimsel ve teknolojik gelişmeler açısından da gelişmiş ülkeler bilgisayar çağına geçerken, ABD nükleer başlıklı füzelere karşı uzaydan koruma kalkanları (Strategic Defense Initiative, 1983) geliştirirken, SSCB burada da geride kalıyordu. ${ }^{9}$

\subsubsection{Dış Siyasette Gorbaçov'un Parlayan Yıldızı}

SSCB'nin lideri Gorbaçov ile yıldızının parladığı tek alan belki de dış siyasetti. Ülkenin yaşadığı ekonomik sıkıntılarla da bağlantılı olarak, Gorbaçov Soğuk Savaşın yarattığı maliyeti azaltmak ve ABD'de iktidarda olan Ronald Reagan'in (1981-1989) sertlik yanlıs1 siyasetine rağmen bir yumuşama dönemine geçmek istiyordu. 27. Parti Kongresinde Gorbaçov Batı ile uygar ilişkiler kurulması, nükleer silahların ve askeri harcamaların azaltılmasını parti üyelerinin önüne koydu. Ardından Afganistan'dan geri çekilme sürecini başlattı. Kasım 1985'te

\footnotetext{
${ }^{7}$ Mihail S. Gorbaçov, Oktyabr i perestroyka: revolutsia prodoljaetsa, Politizat, Moskova 1987.

${ }^{8}$ Chris Miller, The Struggle to Save the Soviet Economy. Mikhail Gorbachev and the Collapse of the USSR, The University of North Carolina Press, Chapel Hill 2016.

${ }^{9}$ Ralph L Dietl, The Strategic Defense Initiative: Ronald Reagan, NATO Europe, and the Nuclear and Space Talks, 1981-1988, Lexington Books, Maryland 2018.
} 
Cenevre'de, ardından Ekim 1986'da Reykjavik'te iki lider bir araya geldiler. ${ }^{10}$ Bu ziyaretler sonraki y1llarda ve Reagan'ın halefi George H. W. Bush (1989-1993) döneminde de devam etti ve gerek görüşmeler sırasındaki samimi fotoğrafları gerekse eşleriyle beraber verdikleri aile fotoğraflarıyla sıcaklaşan ilişkileri dünyaya yansıttılar.

Gorbaçov, uluslararası ilişkiler alanında sadece ABD ile ilişkileri yeni bir çerçeveye oturtmad1; Doğu Bloku üyesi Doğu Avrupa ülkelerine yönelik Sovyet politikasını da değiştirdi. 1968 Çekoslovakya isyanı sırasında Brejnev'in açıkladığı herhangi bir sosyalist ülkeyi kapitalizme döndürme yolunda yapılacak girişimin tüm sosyalist ülkeleri ilgilendireceğine dair meydan okuma yerine, ${ }^{11}$ Gorbaçov ülkelerin kendi kaderlerini kendilerinin belirlemesine karışmamayı tercih etti. Böylelikle Doğu Avrupa'da başlayan devrimlere müdahale etmedi ve 1989'da Demokratik Almanya Cumhuriyeti, Polonya, Çekoslovakya, Macaristan, Romanya ve Bulgaristan'da komünist partiler otoritelerini yitirdiler. Berlin Duvarı yıkıldı ve 1990'da iki Almanya'nın birleşmesine de SSCB müdahale etmedi. Bunlar elbette Gorbaçov'un Batı'da popülerini artıran etkenler arasında sayılabilir.

\subsubsection{Milliyetçi Protestolar ve Dağılmaya Giden Yol}

SSCB'nin içinde de kontrolün Moskova'nın elinden çıkmaya başladığına işaret eden karışıklıklar yaşanıyordu. 1986'da Kazak Sovyet Sosyalist Cumhuriyeti'nin başkenti AlmaAta'da (bugün Almatı) Aralık 1986'da büyük protesto gösterileri yapıldı. Bugün Jeltoksan (Kazakça Aralık ayı) isyanı olarak anılan ve Kazak bağımsızlık mücadelesinin işaret fişeği gibi kabul gören bu isyan, Kazak SSC'nin yönetimine Gennadiy Kolbin adında Kazak olmayan, merkezden birinin atanması nedeniyle çıkmıştır. Kolbin, Gorbaçov tarafından Kazak SSC'deki yaygın yolsuzlukla mücadele için atanmış biri olsa da, bu hareket alma-Ata'da büyük tepkiyle karşılanmıştır.

1988 'in Ocak ayında Azerbaycan SSC'ye bağlı Karabağ Özerk Bölgesi'nde çıkan silahlı ayaklanma ve sorunun Azerbaycan SSC ile Ermenistan SSC arasında bir probleme dönüşmesi, Azerbaycan'da milliyetçi Halk Cephesinin kuruluşu ve Bakü'de protestoların Kasım 1988'de Moskova'nın müdahalesiyle kanlı șekilde bastıılması, SSCB içinde milli sorunların da biriktiğini gösteriyordu. ${ }^{12}$

SSCB'nin çözülmesine giden olaylar zinciri ise Baltık cumhuriyetlerinde başladı. Baltık Körfezindeki üç Sovyet cumhuriyeti Litvanya, Letonya ve Estonya 1940'ta SSCB tarafından ilhak edilmiş (veya geri alınmış); bu nedenle Moskova açısından "huzursuzluk kaynağı" olarak görülen bir bölgeydi. ${ }^{13}$ Haziran 1988 'de Litvanya'da kalabalık gruplar 1940 'tan beri bask1 altında tutulan milli kimliklerini kutlamak için meydanlarda toplandı. Bağımsızlıklarını kaybetmelerine neden olan, kötü şöhretli Hitler-Stalin Paktının kırkıncı yılı olan 23 Ağustos 1989'da yaklaşık iki milyon kişinin katılımıyla üç ülke boyunca bir insan zinciriyle Sovyet işgalini protesto ettiler. Litvanya'da 1990 Şubat'ında yapılan ilk meclis seçimlerini bağımsızlık hareketine önderlik eden Sajudis (hareket) kazandı ve Litvanya 11 Mart 1990'da bağımsızlığını ilan etti. ${ }^{14}$

\footnotetext{
${ }^{10}$ Jonathan Dean, Meeting Gorbachev's Challenge: How to Build Down the NATO-Warsaw Pact Confrontation, Palgrave Macmillan, London 1989.

11 Vladislav M. Zubok, A Failed Empire: The Soviet Union in the Cold War from Stalin to Gorbachev, The University of North Carolina Press, Chapel Hill 2007, s. 207-209.

${ }^{12}$ Brown, age, s. 262-264.

${ }^{13}$ Thomas Kunze, Thomas Vogel, Das Ende des Imperiums: Was aus den Staaten der Sowjetunion wurde, Ch. Links Verlag, Berlin 2015, s. 61.

${ }^{14}$ Kunze, age, s. 63.
} 
Merkezkaç güçlerin artan etkisi isyanlar ve karışıklarla diğer cumhuriyetlerde de kendini gösterdi. 1990 Nisan'ında Gürcistan SSC'nin başkenti Tiflis'te protestolar bastırıldı. ${ }^{15}$ Mayıs'ta Özbekistan'a ait Fergana Vadisi'nde Ahıska Türkleri ile Özbekler arasında çıkan olaylarda çok sayıda kişi öldü ve 70 binden fazla Ahıskalı Özbekistan'1 terk etti. 1990 Haziran'ında bu sefer Fergana Vadisi'nin Kırgız SSC tarafında Kırgızlar ve Özbekler arasında çıkan etnik çatışmada çok sayıda kişi hayatını kaybetti.

\subsubsection{SSCB'nin Dağılışı}

18-21 Ağustos 1991'de çözülmeye giden SSCB'de bu gidişi durdurmak için askeri darbe girişimi yaşandı. Ülke içinde gerekli desteği bulamayan bu darbe girişimi bastırıldıktan sonra SSCB'nin dağılması hizlandı ve 20 Ağustosta Letonya, 21 Ağustosta Estonya, 24 Ağustosta Ukrayna, 27 Ağustosta Moldova, 31 Ağustosta Kırgizistan, 1 Eylülde Özbekistan bağımsızlı̆̆ını ilan etti. 8 Aralık 1991'de Rusya Federasyonu, Belarus ve Ukrayna SSCB'nin dağıldığını açıklayan anlaşmayı imzaladılar. Nihayetinde 26 Aralık 1991'de SSCB resmen dağıld1.

Gorbaçov'un büyük umutlarla başlayan SSCB'yi yeniden ilerleme rotasına sokma çabası, böylelikle tam tersine ekonomik gerileme, glasnost ile kendini gösteren milli sorunların yükselişi ve dağılma ile sonuçlandı. Günümüzde Gorbaçov Batı'da halen 20. yüzyılın en önemli devlet adamlarından biri olarak görülse de, Kırgızistan'da olduğu gibi eski Sovyet cumhuriyetlerinde o dönemi yaşamış kuşak tarafından SSCB'yi yıkan adam olarak olumsuz şekilde anılıyor.

\section{Görüşme Verileri: Kırgız Halkının Gorbaçov Hakkındaki Görüşleri}

$\mathrm{Bu}$ bölümde Sözlü Tarih Araştırması verilerinin “içerik analizi” bulgularına yer

Volume 12

Issue 3

June

2020 verilmektedir. İlgili Sözlü Tarih Projesi verileri, Çarlık Rusya dönemindeki 1916 sürgününden başlayarak Kırgızistan'ın bağımsızlığını kazandığı yıllara kadar yaşanan tarihsel konuları içermektedir. Bu makale kapsamında ise sadece Gorbaçov ve dönemi hakkındaki veriler derlenmiştir. Görüşme içerikleri ilk aşamada amaca uygun olacak şekilde temalara ayrılmış, tematik içeriklerden elde edilen veriler doğrultusunda kodlama yönergesi oluşturulmuştur. Veriler, güvenirliğin sağlanması için iki araştırmacı tarafından bağımsız olarak kodlanmış ve yönerge ortak kodlamalar üzerinden yeniden revize edilmiştir. Kodlama yönergesinin içerikleri genelleştirme ve indirgeme riski taşımaması için kategorilerin; homojen olmasl, bütünsellik taşımasl, aylrt edici olması, objektif olmast, amaca uygun ve anlaml olması (Bilgin, 2014:1214) gibi kriterler dikkate alınmıştır. Bu yönerge doğrultusunda veriler, Gorbaçov'a yönelik bakış açısını belirlemek üzere "olumlu, olumsuz, olumlu ve olumsuzun bir arada olması ve nötr” görüşler şeklinde kategorilere ayrılmıştır. Bu ayrım görüşmecilerin Gorbaçov'u savundukları ve eleştirdikleri argümanlar çerçevesinde oluşturulmuştur. Ayrıca görüşmecilerin olumlu ve olumsuz argümanları da kendi içinde kategorilere ayrılmıştır. Tematik içeriklerin birden fazla olduğu görüşmelerde çoklu kodlama yapılmıştır.

Yapılan 48 görüşme içinden Gorbaçov hakkında değerlendirmelerin yer aldığı 40 görüşmede sadece 6 kişinin (\% 15) olumlu, 25 kişinin (\% 62,5) olumsuz görüş belirttiği, 5 kişinin (\% 12,5) Gorbaçov'a hem olumlu hem olumsuz özellikler atfettiği, 4 kişinin (\% 10) nötr olduğu tespit edilmiştir. Bu da görüşmecilerin önemli bir kısmının Gorbaçov hakkında olumsuz görüşte olduğunu, yani Batı'daki imajının tersine, Kırgızistan'ın bağımsızlık kazanmasının yolunu açsa da kendisinin açıkça olumsuz bir siyasetçi olarak algılandığını göstermektedir.

${ }^{15}$ Brown, age, s. 264-267. 


\subsection{Gorbaçov Hakkındaki Olumsuz Görüşler}

Gorbaçov aleyhine görüş bildiren 25 görüşmecinin fikirleri yedi kategoride sınıflandırılmıştır. Birden fazla olumsuz argümanın yer aldığı görüşme içeriklerinde çoklu kodlama yapılmış ve çoklu kodlama ayrıştırıldığında toplam 47 olumsuz görüş elde edilmiştir. Olumsuz görüş kategorileri Tablo 1'de yer almaktadır:

Tablo 1. Gorbaçov Hakkındaki Olumsuz Görüş Kategorileri

\begin{tabular}{|c|l|c|c|}
\hline \multicolumn{2}{|l|}{ Olumsuz Görüşler } & F & $\%$ \\
\hline 1 & Birliği dağıtması / Sovyet halkını yok etmesi / düzeni bozması & 16 & 34 \\
\hline 2 & $\begin{array}{l}\text { Dış güçler ile işbirliği yapması, dış güçlerce kandırılması, Birliği } \\
\text { satması (Dış güçler: Amerika, Batı, kapitalistler, Yahudiler) }\end{array}$ & 11 & 23,4 \\
\hline 3 & Halkın fakirleşmesi, yaşamın güçleşmesi & 7 & 14,9 \\
\hline 4 & Kolektif malların adaletsizce satılması/yağmalanması & 5 & 10,6 \\
\hline 5 & Komünist partiyi dağıtması / komünizmi yok etmesi & 4 & 8,5 \\
\hline 6 & $\begin{array}{l}\text { Kapitalizmi getirmesi (hırsılı̆ğa ve adaletsizliğe neden olan pazar } \\
\text { ekonomisine geçilmesi) }\end{array}$ & 2 & 4,3 \\
\hline 7 & İç çekişmelere/çatışmalara yol açması (boylar arasında) & 2 & 4,3 \\
\hline \multicolumn{2}{|l|}{ Toplam } & 47 & 100 \\
\hline
\end{tabular}

Tablo 1'de görüldüğü üzere, Gorbaçov ağırlıklı olarak "Birliği dağıtması / Sovyet halkını yok etmesi / düzeni bozması" (\% 34), "Dış güçler ile işbirliği yapması, dış güçlerce kandırılması, Birliği satması" (\% 23,4) ve "Halkın fakirleşmesi, yaşamın güçleşmesi" $(\% 14,9)$ nedenleriyle suçlanmaktadır. Yedi kategori içinde bu üç kategorinin ağırlığı \% 72,3'tür. Bu üç kategori ve buradaki sınıflandırmada ortaya çıkan yedi kategori de birbiriyle bağlantılı ve birbirini destekleyen olgulara işaret etmektedir. Genel olarak SSCB'nin dağılması ve sonrasında halkın karşılaştığı fakirleşme, adaletsizlik, hırsızlık, çatışmalar nedeniyle suçlanmaktadır. Bunun da "kandırıldığı" veya "satın alındı̆̆ı" için olduğu görüşü yaygındır.

\subsubsection{Birliği Dağıtan Kişi Olarak Gorbaçov}

Yukarıdaki alıntıda görülen genel yargılar dışında, özel olarak bakıldığındaysa, "Birliği dağıtması / Sovyet halkını yok etmesi / düzeni bozması" (\% 34) Gorbaçov’a yönelik olumsuz bakışın ağırlıklı nedenini oluşturmaktadır. Aslında aşağıda görüleceği üzere diğer nedenler de, "SSCB döneminde iyi bir hayat sürdürülürken, bunun bozulmuş olması" algısına dayanmakta, dolayısıyla bunu desteklemektedir. Bu nedenle, Gorbaçov'un suçlanmasının temel nedeninin "Birliği dağıtması" olduğu doğrulanmaktadır. Bununla ilgili düşünceler şu cümlelerle ifade edilmiştir:

Perestroyka dedikleri kötü bir şeymiş. (...) Sovyetler Birliği’ni yeniden yapılandıracağız derken tam tersine yıktılar. (...) Tekrar tekrar Amerika'ya giderek, Berlin Duvarını yıkarak Gorbaçov'a Sovyetler Birliğini sattı diyebiliriz. Yeltsin de katkıda bulunmuş. ${ }^{16}$

SSCB’yi yıkan sözünü ettiğim üç haindir. (...) Onların üçünü hapse atmak lazımdı. Hapse atılmadılar. Bu tarafa bakarsan hainler artık her şeye sahip olmuşlar. Çare yok. Canım yanıyor. ${ }^{17}$

${ }^{16}$ Gülbara Düyşenaliyeva, Bişkek, Nisan 2007.

${ }^{17}$ Kalkanbay Aşımbayev, Isıkköl, Mayıs 2007. 
Bu suçlamalar sırasında Gorbaçov için "sahtekar"18, "hain"19, "aptal”20 şeklinde hakaretler de kullanılmış, ona beddua edildiğini veya ettiğini dile getirenler ${ }^{21}$, hatta "Gorbaçov'u şimdi de öldürtmek gerekir, yine bir yere gidip böyle sorun çıkaracaktır", 22 "O da diriyken ölü oldu. Diriyken toplum onu ölü olarak gördü. Biri bana neden vurmuyorlar onu diye sorduğunda ben zaten ölü insan vurulmaz dedim", 23 "Komünist Parti Gorbaçov'un kurşuna dizilmesini isteyip çok doğru yapmıştı ama o hala sağ "24 ${ }^{20}$ zoleriyle ona olan nefretin ulaştığı boyutu yansıtanlar olmuştur.

Burada ilginç olan, Kırgızistan'ın bağımsız olmasına şükran duymak yerine, insanların "Birlik dağıtıldı", Birlik olarak daha güçlüydük" algısına sahip olmasıdır. Bunun nedeni aşağıda görüleceği gibi bağımsızlık sonrasında karşılaşılan sorunlar ve artık yitip gitmiş eski döneme duyulan nostalji ile ilgidir.

\subsubsection{Dış Güçlere Satılmış veya Aldatılmış Kişi Olarak Gorbaçov}

En sık dile getirilen ikinci olumsuz görüş (\% 23,4), Gorbaçov'un "Dış güçler ile işbirliği yapması, dış güçlerce kandırılması, Birliği satması" yargısına dayanmaktadır. Gorbaçov'u Birliği satmakla suçlayanlardan bazıları onu bu nedenle "Komünist partiyi dağıtması/ komünizmi yok etmesi" $(\%$ 8,5) ile de suçlamaktadır.

Yapılan görüşmelerden seçilen aşağıdaki örnek cümleler, görüşmecilerin bu iki kategorideki görüşlerini yansıtmaktadır:

Gorbaçov (...) Amerika’ya gitmiştir. Yeltsin de gitmiştir. (...) Gittiğinde söz verdiklerini duyduk. Komünist

Partisini dağıtacağım, yok edeceğim dediğini.., geldikten sonra dediğini yaptı. ${ }^{25}$

Tekrar tekrar Amerika'ya giderek, Berlin Duvarını yıkarak Gorbaçov'a Sovyetler Birliğini sattı diyebiliriz. Yeltsin de katkida bulunmuş. ${ }^{26}$

Volume 12

Issue 3

June

2020

Gorbaçov kendisi gazetede yazmıştı: "Ben komünizmi yok edecektim, görevimi yerine getirdim. Bana [Eduard] Şevardnadze, [Aleksander] Yakovlev'ler yardım ettiler diye. Ne zaman satıldı, nasıl oldu, sadece SSCB değil bütün demokrasi sisteminin hepsine zarar verdi. Bundan dolayı Nobel ödülü aldı. Şimdi para sayesinde korunmaktadır. Ama o da diriyken ölü oldu. ${ }^{27}$

Gorbaçov büyük hainlik yaptı. (...) biri Gorbaçov'u satın alan paranın, yabancıların hesabına göre 2 milyar 600 milyon olduğunu söyledi. (...) Yahudilerin gücü ile onlara satıldı. ${ }^{28}$

Onu kapitalistler parayla satın aldılar. Bana göre o canlı ama ölü. Şu an ise kaçarak yaşıyor. Bunun nesi iyi. Onu halk hiç sevmiyor. ${ }^{29}$

Bu örneklerde görüldüğü üzere "Gorbaçov'un satıldığı" hakkında neredeyse bir fikir birliği vardır. Bunun yukarıda anlatılan ABD ziyaretleri ve Ekim 1986'da Reykjavik'te ABD Başkanı Ronald Reagan ile gerçekleştirilen zirveler $^{30}$ sırasında yapılan anlaşmalarla gerçekleştiği düşünülüyor. 1989'a kadar Gorbaçov ve Reagan- 1989 sonrasında ise George H. W. Bush ile sürdürülen ikili görüşmelerde, özellikle dışarıya kapalı toplantılar sırasında Gorbaçov'un "satın

${ }^{18}$ Almunzak Araev, Panfilov, Çüy, Nisan 2007.

${ }^{19}$ Kalkanbay Aşımbayev, Isıkköl, Mayıs 2007; Orozbek Düyşeev, Talas, Mayıs 2007.

${ }^{20}$ Almunzak Araev, Panfilov, Çüy, Nisan 2007.

${ }^{21}$ Bübüsayra Omorova, Beş-Küngöy, Mayıs 2007.

${ }^{22}$ Almunzak Araev, Panfilov, Çüy, Nisan 2007.

${ }^{23}$ Kalkanbay Aşımbayev, Isıkköl, Mayıs 2007.

${ }^{24}$ Toktor Turgunbekov, Talas, Mayis 2007.

${ }^{25}$ Karabay Alakunov, Narın, Mayıs 2007.

${ }^{26}$ Gülbara Düyşenaliyeva, Bişkek, Nisan 2007.

${ }^{27}$ Kalkanbay Aşımbayev, Isıkköl, Mayıs 2007.

${ }^{28}$ Orozbek Düyşeev, Talas, Mayıs 2007.

${ }^{29}$ Köçkön Saktanov, Alay, Oş, Mayıs 2007.

${ }^{30}$ Dean, age, s. 1989. 
alındığı" düşünülüyor, hatta bunun için Gorbaçov'a verilen paranın miktarı bile telaffuz ediliyor. Bu satılmışlığı nedeniyle, çok para almış olsa da artık "yaşarken ölmüş" söyleniyor.

$\mathrm{Bu}$ "satılmışlık" suçlamasının altında muhtemelen halkın onun tıkanan bir sistemi düzeltmek için yaptıklarına akıl erdirememesi yatmaktadır. Görüşmecilere göre, "yeniden kurmak isterken yıktığı" sistem zaten "işleyen bir sistem" idi. Bunu yıkıp halkın yoksulluk, adaletsizlik, yolsuzluk ve çekişmelerle dolu bir hayata mahkum edilmesinin altında makul bir neden göremediğinden, insanlar onu satılmışlıkla suçlamakta, onu bugünkü sorunlarının baş sorumlusu olarak görmektedirler.

\subsubsection{Sorunlarm Suçlusu Olarak Gorbaçov}

Olumsuz görüşler içinde dile getirilen "Halkın fakirleşmesi, yaşamın güçleşmesi” ( $\% 14,9)$, "Kolektif malların adaletsizce satılmasi/yağmalanması" (\% 10,6), "Kapitalizmi getirmesi (hırsızlığa ve adaletsizliğe neden olan pazar ekonomisine geçilmesi)" (\% 4,3) ve "İç çekişmelere/çatışmalara yol açması (boylar arasında)" (\% 4,3) kısmen onun dönemindeki perestroyka sırasında devletin hâkimiyetindeki planlı ekonomik sistemin gevşetilmesi sırasında başlamıştır; ancak bu sorunlar asıl olarak bağımsızlıktan sonra serbest piyasa ekonomisine geçişin doğurduğu sorunlardır ve dolaylı olarak onunla ilgili, beklenmedik sonuçlardır.

İfade edilen diğer nedenlerin bir kısmı yukarıda anlatıldığı gibi perestroykayla başlatılan ekonomik reformların, yetersiz de olsa işleyen sistemin çökmesine neden olmasındandır. Ancak hatırlanan sorunların çoğu, doğrudan onunla değil, iradesi dışında SSCB'nin dağılması ve Kırgızistan'da şok terapi ile geçilen sistemin yarattı̆̆ 1 sorunlarla ilişkilidir. Buradaki "Kapitalizmi getirmesi (hırsızlığa ve adaletsizliğe neden olan pazar ekonomisine geçilmesi)" aslında bağımsızlık sonrasında Kırgızistan Cumhurbaşkanı Askar Akayev'in tercihiydi. Kırgızistan'da piyasa ekonomisine geçerken gerçekleştirilen özelleştirmeler sırasında "Kolektif malların adaletsizce satılması/yağmalanması", ardından 1993-1994 yıllarındaki derin ekonomik kriz, şikâyetler arasında yer alan "Halkın fakirleşmesi, yaşamın güçleşmesi”"ne neden olmuştu.

Burada Kırgızistan'ın, 31 Ağustos 1991'de bağımsızlığı aldıktan sonra yaşananları hatırlamakta fayda vardır. Bağımsızlıktan hemen sonra ülkede siyaseten çoğulcu, parlamenter demokratik sistem, ekonomik olaraksa serbest piyasa ekonomisi benimsenmiştir. Kırgızistan'ın ihtiyaç duyduğu yatırımları çekmesi için Cumhurbaşkanı Akayev liderliğinde 20 Aralık 1991'de ekonomide devlet kontrolüne dayalı sosyalist sistemden çıkıp liberalizmin gereklerine göre işleyecek bir sistemin temellerini atmak üzere "Özelleştirme ve Girişimciliğin Genel Esasları" adlı yasa tasarısı onaylandı. Bu çerçevede atılan ikinci adım, yabancı yatırımcıları ülkeye çekmek için 6 Mart 1992'de onaylanan “İmtiyazlar ve Yabancı İmtiyazlı İşletmeler" ile ilgili yasa tasarısıdır (Lud, 1999: 66). 3 Ağustos 1992'de kabul edilen ekonomi programıla başlatılan özelleştirmelerle fabrika ve sovhozlarda (devlet çiftliği) çalışanlar çalıştıkları yerden pay aldılar, kolhozdakilere de (kooperatif) işledikleri toprak verildi ve devlet elindeki üretim vatandaşlar arasında dağıtılmış oldu. ${ }^{32}$ Bunlar Kırgızistan'ın IMF ile görüşmeleri sonucunda, liberal ekonominin yerleştirilmesi için girişilen şok terapinin parçası olarak atılan adımlardı. ${ }^{33} 8$

\footnotetext{
${ }^{31}$ Kalkanbay Aşımbayev, Isıkköl, Mayıs 2007; Köçkön Saktanov, Alay, Oş, Mayıs 2007.

${ }^{32}$ Yunus Emre Gürbüz, "Demokrasi ve Otoriterlik Sarkacında: Kırgızistan," Bă̆ımsızlıklarının Yirminci Yılında Orta Asya Cumhuriyetleri: Türk Dilli Halklar - Türkiye ile İlişkiler, c.I, ed. Ayşegül Aydıngün, Çiğdem Balım, Atatürk Kültür Merkezi (AKM), Ankara 2012, s. 149.

33 Yunus Emre Gürbüz, "Orta Asya'nın Ortasında bir Ada: Kırgızistan”, Hacettepe Üniversitesi Türkiyat Araştırmaları Dergisi, Hacettepe Üniversitesi Türkoloji Araştırmaları Enstitüsü, C.15, Güz 2011, s. 429.
} 
Mayıs 1992'de IMF'ye kabul edilen Kırgizistan, bu kuruluşun Orta Asya'daki ilk üyesi olmuştur. ${ }^{34}$

Fakat bunları işletmek için gerekli sermayenin vatandaşta olmaması, ayrıca devlet desteğinin de, ulaşım ağının da ortadan kalkması, hayvanlar ve ürünlerin hasadı için gerekli yem, tohum, ilaç, gübre, traktör ve iş aletlerinin eksikliği, hayvanların telef olması, ekinlerin hasadının düşmesi gibi ciddi sorunlar getirmiştir. Sanayi de büyük darbe yemiş ve 1991-1995 arasında her yıl \% 20 oranında küçülmüştür. ${ }^{35}$ Bir de bunların üstüne paranın değer kaybetmesiyle 1992 'de \% 920, 1993 'te \% 1.211,5'lük enflasyon yaşanmıştı. ${ }^{36}$ Bunların sonucunda 1991-1995 arasında Kırgızistan'da GSYİH \% 55,7 küçülmüşs, ${ }^{37}$ açlık ve işsizlik yaygınlaşırken, insanların bağımsızlıkla yükselen umutlarının yerini umutsuzluk almıştır.

Gorbaçov, halkın yaşadığı tüm bu sorunların sorumlusu olarak görüldüğünden son derece olumsuz bir biçimde anılmaktadır. Bu zorluklar hakkında görüşmecilerin dile getirdiği şikâyetlere örnek olarak şunlar gösterilebilir:

İfade özgürlüğü, halk özgürlüğü diyenler soyguncu, hırsız oldular. İnsanları öldürüyorlar. (...) Kırgızistan'da birkaç milyon koyun vardı, çok sayıda at. Çok sayıda fabrikamız çalışıyordu. Nerede onlar. Gorbaçov bulup versin. Perestroykayla, biz zorlukla elde ettiğimizi, kolayca dağıttık diye düşünüyorum. ${ }^{38}$

Brejnev'in topladıklarını o öldükten sonra Gorbaçov har vurup harman savurdu. Sovyetler Birliğ kurulduğunda halk ekmeği bedava yerdi, bir kuruş bile zimmetine geçiremezdi. Ev kiraları ucuzdu. Şimdi o kadar pahalı ki parasını zar zor verirsin. Hayvanları besleyelim diye ağıllar kuruldu. Şimdi ise her şey talan oldu. ${ }^{39}$

Rusya'yı Batı aldattı. Neden aldattı? Onlar demokrasi ve özelleştirme yolunda gitmezseniz yaptı̆̆ınız bütün reformlar yanlış dediler. Onların söylediklerini yaptık. Ortak malı özel yaptık. Örneğin, bu dönemlerde milyonlarca koyun yok oldu. Çünkü hiç kimse beslemedi. (...) Bundan sonra hiç gelişemedik. Halkın yaşamı kötülești. O zamanlar bazı evlere gittiğimizde sadece su ile yaylada oturan aileler çoktu. ${ }^{40}$

Gorbaçov çok etki yarattı. Bağımsız olduk. Bağımsızlığın ilk yılları çok ağır geçti. 5-6 yıl açlık yaşandı. Az kalsın ölecektik. Çürümüş ekmek de yedik. Sonra yavaş yavaş iyileşti, şimdi iyi, sofra dolu. Fakat her şey pahali. $^{41}$

Gorbaçov'un döneminde olmalı mallardan zorluk çektik, mallar yeterli ölçüde bulunmuyordu, halka fiş karşılığında dağıtıyorduk (...) 80li yıllarda değil, daha sonra halk o zaman çok zorlandı, Gorbaçov'u lanetleyenler, bağırıp çağıranlar oldu. Önceki hayatımız iyiydi, perestroyka çıktı bütün yiyecekler ortadan kalktı, halk yağmaya kalktı, ekmek de ortadan kalktı diye halk çok zorlandı. ${ }^{42}$

$\mathrm{Bu}$ örneklerde görüldüğü gibi Gorbaçov döneminde perestroykayla başlayan değişim ve onun getirdiği yıkım ile bağımsızlığın ilk yıllarındaki ekonomik geçişle sorunların keskinleştiği yaklaşık on yıllık süre, insanların zihninde iç içe geçmiş görünmektedir. Bu şikayetlerde bahsi geçen fabrikaların işlemez hale gelmesi ve yiyecek kıtlığı Gorbaçov'un son yıllarında yaşanmaya başlayan, sonra da devam eden zorluklardır, ancak özelleştirmeler, piyasa ekonomisine geçiş, enflasyon aslında bağımsızlık sonrası yaşanan olaylardır.

\footnotetext{
${ }^{34} \mathrm{http} / / / \mathrm{www} . \mathrm{imf}$. org/external/country/kgz/rr/index.htm, erişim tarihi: 10.02.2020.

${ }^{35}$ Rafis Abazov, Historical Dictionary of Kyrgyzstan, Oxford 2004, s. 7-8.

${ }^{36}$ Haluk Alkan, Orta Asya Türk Cumhuriyetlerinde Siyasal Hayat ve Kurumlar: Kazakistan, Özbekistan, Kirglzistan, Türkmenistan, USAK Yayınlar1, Ankara 2011, s. 219.

${ }^{37}$ Paul Kubicek, "Authoritarianism in Central Asia: Curse or Cure?", Third World Quarterly, C. 19, No. 1: 1998, s. 33.

${ }^{38}$ Gülbara Düyșenaliyeva, Bişkek, Nisan 2007.

${ }^{39}$ Mamacali İsayev, Karateyit, Nisan 2007.

${ }^{40}$ Köçkön Saktanov, Alay, Oş, Mayıs 2007.

${ }^{41}$ Ubaydulda Ümetaliev, Narın At-Başı, Mayıs 2007.

${ }^{42}$ Tursun Ayılçieva, Talas, Mayıs 2007.
} 
Bunlardan ayrı duran bir başka eleştiri Gorbaçov'un “iç çekişmelere/çatışmalara yol açması (boylar arasında)" (\% 4,3) sorunudur. Burada kast edilen, Sovyetler Birliği'ni zayıflatmak isteyenlerin Gorbaçov’u kandırarak, Birliği milletlere ve boylara böldüğü yargısıdır. Aşağıdaki örnek bunu yansitmaktadir:

Halkı bozmak için halkı bölmek gerekti. Boy boy bölmek, milletlere bölmek gerekti. Gorbaçov'u baştan çıkaranlar bunlara da el attılar. Akılsızlar, dolayısıyla bir boy ile diğeri kavga ediyor. (...) Egemen olacağız diye halk yanlış yola düştü. Tersine birleşmeleri lazımdı. (...) Egemen olmadan önce bizimkiler Sovyetler Birliği topraklarında serbest dolaşırlardı. Nereli olduğumuzu hiç düşünmezdik. Şimdi bizim zavallı Kırgız çocuklarımızı dövüyorlar, bölüyorlar. İnsanoğlu geliştikçe akıl yolunda birleşmesi lazım. Kabileler halinde yaşadıkları zamanlarda elbette bir mamutu vurduklarında, ona sahip olmak için savaşmak gerekiyordu. Şu an bundan ne yararın olur. ${ }^{43}$

Burada görüldüğü gibi milletlere veya boylara bölünmek yerine Birlik içinde kalmanın önemine çarpıcı örneklerle vurgu yapılmakta, hatta Kırgızistan'ın bağımsız olmasına bile olumsuz bakılmaktadır. Bununla birlikte Kırgızistan'da boyların boylar ile kavgalı olduğuna, sadece SSCB olarak milletlere bölünülmediğine, ayrıca Kırgızistan içinde de boylara bölünüldüğüne değinilmektedir. Kırgızistan'da tribalism (kabilecilik) olarak adlandırılan durum, Batılıların üstünde en çok çalışma yaptıkları alanlardan biridir ve bu çalışmalarda boya veya bölgeye dayalı ayrımların Kırgızistan'da belirleyici olduğu üstünde durulmaktadır. ${ }^{44}$

$\mathrm{Bu}$ sorun da öncekiler gibi sadece Gorbaçov ile bağlantılı değildir. Gorbaçov, SSCB’nin yıkılışı sırasında yaşanan ve yıkımın getirdiği tüm güçlüklerin sorumlusu olarak görülmekte ve Kırgızistan'ın karşılaştığı tüm güçlükler için bir “günah keçisi” olmaktadır.

\subsection{Gorbaçov Hakkındaki Olumlu Görüşler}

Sayısı az da olsa elbette ki Gorbaçov hakkında olumlu görüşler de vardır. Yapılan 48 görüşme içinden Gorbaçov hakkında görüşlerin yer aldığı 40 görüşmede sadece 6 kişinin (\% 15) olumlu bakış açısına sahip olduğu görülmüştür. $\mathrm{Bu} 6$ görüşme çoklu kodlama ile çözümlendiğinde 8 ayrı kategoride sınıflandırılabilen toplam 10 olumlu görüş tanımlanmaktadır. Olumsuz görüşlere göre burada daha dağınık bir durum ortaya çıkmaktadır. Tablo 2'de Gorbaçov hakkındaki olumlu görüşlerin dağılımı gösterilmektedir.

Tablo 2. Gorbaçov Hakkındaki Olumlu Görüş Kategorileri

\begin{tabular}{|l|l|l|}
\hline Olumlu Görüşler & f & $\%$ \\
\hline Gorbaçov zamanında sanayi, teknoloji ve bilimsel alandaki gelişmeler & 2 & 20 \\
\hline Gorbaçov'un bağımsızlığa giden yolu açması & 2 & 20 \\
\hline Ülke sınırlarını açması & 1 & 10 \\
\hline İfade özgürlüğü getirmesi & 1 & 10 \\
\hline Akıllı ve bilgili olması & 1 & 10 \\
\hline
\end{tabular}

\footnotetext{
${ }^{43}$ Orozbek Düyşeev, Talas, Mayıs 2007.

${ }^{44}$ Bu konudaki geniş literatür için örneğin bkz. Örneğin bkz.: Kathleen Collins, Clan Politics and Regime Transition in Central Asia, Cambridge University Press, Cambridge 2006; David Gullette, "The Problems of the "Clan" Politics Model of Central Asian Statehood: a Call for Alternative Pathways for Research", Stable Outside, Fragile Inside?: Post-Soviet Statehood in Central Asia, ed. E. Kavalski, Farnham, Ashgate, 2010, s. 53-69; Edward Schatz, Modern Clan Politics: the Power of Blood in Kazakhstan and Beyond, University of Washington Press, Seattle 2004; David Gulette, "Tribalism in Kyrgyzstan Examined", Central Asia and Caucasus, 2 (14), 2002, s. 31-37; Altynbek Joldoshov, "Kabilecilik, Bölgecilik ve Etnisite: Kırgız Kimliği Üzerine Çalışmalar”, OAKA, C.8, S.15, 2013, s. 101133.
} 


\begin{tabular}{|l|l|l|}
\hline Dünyada itibarının iyi olması & 1 & 10 \\
\hline İyi ve dürüst olması & 1 & 10 \\
\hline Halkın kardeşçe yaşaması, şiddetin olmaması & 1 & 10 \\
\hline Toplam & 10 & 100 \\
\hline
\end{tabular}

Tablo 2'de görüldüğü üzere Gorbaçov farklı sebeplerle olumlu olarak algılanmaktadır. İnsanların onu neden olumlu gördüğü aşağıdaki görüşme örneklerinde yansıtılmaktadır:

... O bütün sınırı açtı ve bize dünyayı tanıttı. Eğer hala o devirde yaşasaydım çantanın ne tür malzemeden yapıldığını, cebindeki telefonunu hiç bilmeyecektim. Şimdi ise ilime kavuştuk, geliştik. ${ }^{45}$

Gorbaçov'un niyeti iyiydi, kendisi çok akılll, bilgili kişiydi, o uzlaşma ustasıydı... Bütün dünyada Gorbaçov'un etkisi ve itibarı büyüktür. Dünyada kimsenin ortadan kaldıramadığı SSCB'yi ve güçlü Komünist Partisini Gorbaçov'un devirdiği düşünülüyor, gerçekten de böyledir. ${ }^{46}$

O olmadan bu bağımsızlık... Bağımsızlık, Allah'a şükür, bizim için iyi oldu. ${ }^{47}$

... Ondan çok memnunum, ölenlerin ruhları da memnun [1938'deki parti içi tasfiyeler sırasında öldürülenleri kastediyor], çünkü o söz serbestliğini getirdi. (...) Bu sırada ben de anlatarak boynumdaki yükten kurtuldum. Eğer Gorbaçov söz serbestliği vermeseydi belki ölüp bu sırrı kendimle götürecektim. Bunun için memnunum.

$\mathrm{Bu}$ son örnekteki olumlu ifadeler, 1938'de Kırgızistan Komünist Partisi'ndeki tasfiye sırasında öldürülen kişilerin gömüldügü yeri bilen ve yetkililere söyleyerek, buranın açılmasını sağlayan kişiye aittir. Kendisi, bu bilgiyi ancak glasnost sırasında yetkililere bildirebilmiştir. Gorbaçov'un başlattığı glasnost sayesinde Kırgızistanlı 137 aydın ve siyasetçinin gömülü olduğu yerin açılmasını sağlayabildiğinden Gorbaçov’a özel bir minnet duymaktadır.

Bu örneklere bakıldığında Gorbaçov, Kırgızistan'ı SSCB'nin kapalı sisteminden kurtarması, onu dünyaya ve tüketim toplumuna açması, düşünce özgürlügü getirmesi, akılll, bilgili, dünyada itibarı büyük biri olması, bağımsızlık yolunu açması gibi farklı nedenlerle saygı görmektedir. Kendisi hakkındaki olumsuz görüşlerin tersine burada fikir birliğinin olmadığ 1 genel kabul gören ve tekrarlanan görüşlerin bulunmadığı görülmektedir. Onunla ilgili olumlu düşüncelerin dağınıklığı ve sayıca azlığı birbiriyle bağlantılı ve ilişkilidir.

\subsection{Lehte ve Aleyhte Görüşlerle Gorbaçov}

Açık şekilde Gorbaçov'a olumlu veya olumsuz bakanların yanında hem olumlu hem olumsuz taraflarını bir arada ifade edenler de olmuştur. Bu kişiler genelde Birliği dağıtmasını olumsuz olarak algilarken; Birliğin dağılması sonucunda gelenek, görenekler, millî değerler, dini vecibelerin gelişmesi için uygun zeminin oluşmasını olumlu olarak değerlendirmişlerdir.

$\mathrm{Bu}$ şekilde düşüncelerini beyan eden 5 kişinin olumlu ve olumsuz görüş kategorileri Tablo 3'de yer almaktadır.

${ }^{45}$ Abdıkalık Satiev, Bişkek, Nisan 2007.

${ }^{46}$ Asankan Cumakmatov, Bişkek, Nisan 2007.

${ }^{47}$ Kadir Baybosov, Narın, Mayıs 2007.

${ }^{48}$ Bübüra Kıdıraliyeva, Alamüdün, Çüy, Nisan 2007. 
Kırgız Halkının Gözünden Gorbaçov: Bir Sözlü Tarih Çalışması

Tablo 3. Gorbaçov Hakkında Olumlu ve Olumsuz Görüş Kategorileri

\begin{tabular}{|l|l|l|l|l|}
\hline \multicolumn{2}{|c|}{ Olumlu ve Olumsuz Görüşler } & \multicolumn{1}{|c|}{ Olumsuz } & f & $\%$ \\
\hline & \multicolumn{1}{|c|}{ Olumlu } & Birliğin dağılması & 2 & 33,33 \\
\hline 1 & Milli değerlerin yaşanması & Birliğin satılması & 1 & 16,66 \\
\hline 3 & $\begin{array}{l}\text { Din/inanç özgürlüğü } \\
\text { oluşması, egemenliğe kavuşulması }\end{array}$ & $\begin{array}{l}\text { Gorbaçov'un yönetim zafiyeti, } \\
\text { başarısızlı̆ı }\end{array}$ & 1 & 16,66 \\
\hline 4 & $\begin{array}{l}\text { Egemenlik-bağımsızlık yolunun } \\
\text { açılması }\end{array}$ & $\begin{array}{l}\text { Kirgızistan için yararlı işler } \\
\text { yapmaması }\end{array}$ & 1 & 16,66 \\
\hline 5 & $\begin{array}{l}\text { Yenilikler yapması, üretimi geliştirmesi } \\
\text { Birliğin dağılması, hayat şartlarının } \\
\text { iyileşmemesi }\end{array}$ & 1 & 16,66 \\
\hline \multicolumn{2}{|l|}{ Toplam } & & 6 & 100 \\
\hline
\end{tabular}

Görüşmelerden seçilen aşağıdaki örnekler görüşmecilerin kendi ifadeleriyle bu değerlendirmeleri yansıtmaktadır:

Biz, Kırgızlar kendi geleneklerimiz, örf-adetlerimiz ile yaşıyoruz. Bu bir taraftan iyidir, diğer taraftan ise birlik içinde yaşasak daha iyi olurdu. ${ }^{49}$

Gorbaçov geldi, iyi de geldi, ama Birliği yok etti. Bence o satılmış bir adam. (...) Sovyet düzeni yıkıldıktan sonra kendi başımıza ayrı bir ülke olmamız iyi oldu. Eskiden Sovyet düzeninde dini vecibelere izin verilmiyordu. Bağımsızlığı kazandıktan sonra iyi oldu. Müslümanlığın farzlarını yapmaya başladık, camiler açıldı. Din adamları çocuklarımıza eğitim verdi, şu anda dine büyük fırsatlar tanındı. ${ }^{50}$

Buradaki olumlu yargılar Gorbaçov hakkındaki olumsuz yargıların bir kısmında olduğu gibi doğrundan ve isteyerek Gorbaçov'un yaptıklarıyla bağlantılı değildir. Sovyetler Birliği’ni dağıtması ve bağımsızlı̆̆ın kazanılması da bunların sonucunda ortaya çıkan özgürlükler, gelenekler ve milli değerlerin önem kazanması da Gorbaçov'un inisiyatifi dışında olan gelişmelerdir.

\section{Sonuç}

Gorbaçov, SSCB'nin başına geldiğinde başlattı̆̆ı, glasnost ve perestroyka olarak adlandırdığı reformlarla Batı'da umut yaratmış, SSCB'de ise umutla karışık kaygıyla karşılanmıştı. İktidara geldiği yıllar Sovyetler Birliği'nin Afganistan'ı işgali (1979) ve bunu protesto eden NATO ülkelerinin 1980 Moskova Olimpiyatları'nı boykot etmesiyle Soğuk Savaşın sertleştiği bir dönemdi. Gorbaçov'un yumuşama yönünde attığı adımlar Batı'da iyimserliğin artmasını sağlamıştı. 1989-1991 arasında Doğu Avrupa ülkeleri Moskova'nın kontrolünden çıkarken, Gorbaçov yönetimindeki SSCB'nin müdahale etmemesi, düşmanlığın sembolüne dönüşmüş Berlin Duvarı'nın yıkılması ve ardından iki Almanya'nın birleşmesine göz yumulması, onun samimiyetine yönelik inancı arttırarak, Batı'daki popülerliğini de yükseltmişti. Aradan geçen otuz yılın ardından Gorbaçov kısmen unutulsa da, onu hatırlayanlar arasında Batı'da popülerliğini korumaktadır.

SSCB ülkelerinde ise durum farklıdır. Moskova'ya en uzak Sovyet Cumhuriyetleri'nden biri olan Kırgızistan (Kırgız SSC) da diğer cumhuriyetler gibi Gorbaçov'un iktidarının son

\footnotetext{
${ }^{49}$ Ataş Turusbekov, Oş, Mayıs 2007.

${ }^{50}$ Corobay Bayimbetov, Calal-Abad, Mayıs 2007.
} 
yıllarında bağımsızlığını kazanmıştır. Bu nedenle özellikle glasnost hareketiyle gelen özgürlük ortamında bağımsızlığa giden yolu açtı̆̆ından Kırgızistan halkının ona şükran duyması beklenebilir.

Ne var ki bu çalışmada görüldüğü üzere o dönem elli yaşın üstünde olan ve hayatları Sovyet döneminde geçmiş olanların Gorbaçov hakkındaki düşünceleri Batı'dakinin tam tersine son derece olumsuzdur. Bunun temel nedeni pek çok kişinin gözünde Gorbaçov'un "diş güçlerce kandırılmış olduğu" ya da daha kötüsü "dış güçler ile işbirliği yaparak, Birliği sattığı"dır. Bu nedenle onu hakaretamiz ifadelerle ananların sayısı hiç de az değildir. Onun hakkındaki olumsuz yargılar kandırılmış veya satılmış bir hain olduğundan, onu öldürme arzusuna kadar uzanmaktadır.

Gorbaçov sadece kendi döneminde yaşanılanlarla değil, başlattığ çözülmesine yol açması ve ardından gelen bağımsızlık sonrasında liberal ekonomik sisteme

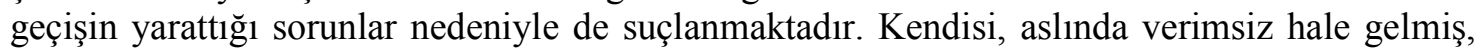
teknolojik ilerleme ve ekonomik büyümede Batı'nın gerisinde kalmış SSCB'yi toparlamak isterken, yıkımına yol açmıştır. Görüşmeciler ise onu "zaten işleyen bir sistemi yıkmak" ile suçlamaktadır.

Gorbaçov'un giriştiği perestroyka, sistemi işlemez hale getirirken, bağımsızlık sonrasında bunu takip eden özelleştirmelerle liberal ekonomiye geçiş ekonomik durumun ve ülkenin üretim altyapısının tamamen çözülmesine yol açmıştır. SSCB döneminde kurulan sistemin mirası fabrika, sovhoz ve kolhozların dağılması sonucunda, üretim sistemi parçalara ayrılıp tamamen işlevsiz hale gelmiş; bu da açlık, yoksulluk, işsizliğin yaygınlaşması ve toplumsal çatışmalar gibi sorunları beraberinde getirmiştir. Tüm bu sorunlar yaşanırken, malların adaletsizce bazı ellerde toplanması, insanların kinini daha da arttırmıştır.

Volume 12

Gorbaçov'dan şikayet edenlerin dile getirdiği sorunlar arasında yer alan "halkın fakirleşmesi, yaşamın güçleşmesi", "kolektif malların adaletsizce satılması/yağmalanması", "kapitalizmi getirmesi (hırsızlığa ve adaletsizliğe neden olan pazar ekonomisine geçilmesi)" ve "iç çekişmelere/çatışmalara yol açması (boylar arasında)" sorunları Gorbaçov'dan çok bağımsızlık döneminde Kırgızistan'ın serbest piyasa ekonomisine geçiş için IMF ile anlaşarak giriştiği şok terapi ile ilişkilidir. Fakat halk bunu Gorbaçov'un reformlarıyla başlayan ve kesintisiz şekilde devam eden bir sorunlar yumağı şeklinde yaşamıştır. Gorbaçov, bunların tamamının başlangıcında yer alan, "Pandora'nın kutusunu açan kişi" olarak günah keçisi konumunu almış ve suçlamaların odağına yerleştirilmiştir. Gorbaçov böylelikle Kırgızistan'ın içine düştüğü tüm sorunların baş suçlusu olarak kabul edilirken, görüşülen kişilerin nezdinde "yaşarken ölmüş" biri haline gelmiştir.

Sayıları az olsa da, insanların düşüncelerini özgürce ifade edebildikleri tüm ülkelerde olduğu gibi Kırgızistan'da görüşülen kişiler arasında farklı düşüncede olan, yani Gorbaçov'a olumlu bakanlar da vardır. Fakat bunların ifade ettiği düşünceler birbirinden farklı, yani dağınık durmaktadır. $\mathrm{Bu}$ da yine genel fikir birliğinin dışında kalmaları ve kendi içlerinde bir fikir birliği oluşturamamalarıyla bağlantılı bir durumdur. Az sayıda kalmaları ve birbirlerinden ayrıksı durmaları bu olumlu görüşlerin kişisel duyarlılıklarla bağlantılı olduğu düşüncesini doğurmaktadır. Bu olumlu ifadeler Gorbaçov'un "Kırgızistan'ı dünyaya açması", "tüketim toplumunun ürünlerini tanımalarını sağlaması", "dünyada çok tanınan ve saygın biri olması", "sayesinde bağımsız olunması", "ifade özgürlüğünün gelmesi” şeklinde ifade edilmiştir.

Gorbaçov hakkında hem olumlu ve hem olumsuz özellikler dile getirenler de olmuştur. Bunlardan olumsuz olanlar Gorbaçov hakkındaki olumsuz düşünce birliğini teyit eden benzer görüşleri yansıtmaktadır. Olumlu düşüncelerse yine farkl1lıklar içermektedir. "Gelenek, 
görenekler”, "millî değerler", "dini vecibelerin gelişmesi için gerekli ortamı sağlaması", "demokrasi ve muhalif görüşlerin oluşması", "egemenliğe kavuşulması", "yenilikler yapması" veya "üretimi geliştirmesi" sözleriyle aktarılan görüşler bu kategoride görülen olumlu yaklaşımlara örnek gösterilebilir.

Hayatının önemli kısmını SSCB döneminde, onun olumlu ve olumsuz özelliklerini şahsen yaşamış bu görüşmecilerin bir kısmı görüşmelerin ardından geçen sürede hayatlarını kaybetmiştir. Fakat düşünceleri kayıtlar sayesinde bundan sonra da tarihe tanıklık etmeye devam edecektir. Benzer çalışmaların şu an 65 yaş üstündeki kişiler arasında da yapılması, onların seslerinin de tarihe geçirilmesi ve kuşaklar arası karşılaştırmalı çalışmalar gerçekleştirerek, akademik çalışmaların sözlü tanıklıklarla tamamlanmasının sürdürülmesi gereklidir.

\section{Kaynakça:}

ABAZOV, Rafis, Historical Dictionary of Kyrgyzstan, The Scarecrow Press, Oxford 2004.

BROWN, Archie, The Gorbachev Factor, Oxford University Press, Oxford 1996.

COLLINS, Kathleen, Clan Politics and Regime Transition in Central Asia, Cambridge University Press, Cambridge 2006.

DADABAEV, Timur \& Hisao Komatsu (ed.), Kazakhstan, Kyrgyzstan, and Uzbekistan: Life and Politics during the Soviet Era, Palgrave Macmillan, Londra 2017.

DADABAEV, Timur \& Kiokuno Nakano Soren: Chyuou Ajia no Hitobito ga Ikita Shyakaisyugi Jidai (Soviet Union Remembered: Everyday Life Experiences of Socialist Era in Central Asia), Tsukuba University Press, Tokyo 2010.

DADABAEV, Timur, "Power, Social Life, and Public Memory in Uzbekistan and Kyrgyzstan," Inner Asia, C.12, S.1, 2010, s.25-48.

DADABAEV, Timur, Identity and Memory in Post-Soviet Central Asia: Uzbekistan's Soviet Past, Routledge, London 2016.

DEAN, Jonathan, Meeting Gorbachev's Challenge: How to Build Down the NATO-Warsaw Pact Confrontation, Palgrave Macmillan, London 1989.

DİETL, Ralph L., The Strategic Defense Initiative: Ronald Reagan, NATO Europe, and the Nuclear and Space Talks, 1981-1988, Lexington Books, Maryland 2018.

ERCILASUN, Guljanat Kurmangaliyeva, "Famines in Kyrgyzstan: The Memories of the 1930s and 1940s", The Journal of Central Asian Studies, C.18, S.1, 2009, s. 63-73.

ERCILASUN, Guljanat Kurmangaliyeva, "Enrichment of Knowledge Through Memory Studies: Oral History Research Projects in Kyrgyzstan", SangSaeng: The Journal of UNESCO Asia-Pacific Centre of Education for International Understanding (APCEIU), 2011, s. 28-31.

ERCILASUN, Guljanat Kurmangaliyeva, "Famine in Kyrgyzstan in the 1930s and 1940s", Kazakhstan, Kyrgyzstan, and Uzbekistan: Life and Politics during the Soviet Era, ed. Timur Dadabaev \& Hisao Komatsu, Palgrave Macmillan, Londra 2017, s. 39-51.

ERCILASUN, Guljanat Kurmangaliyeva, "Kazakistan ve Kırgızistan'da Kolektifleștirme: Sözlü Tarih Çerçevesinden Bir Bakış", Gazi Türkiyat Türkoloji Araştırmaları, S.19, 2016, s. 11-22. 
ERCILASUN, Guljanat Kurmangaliyeva, "Remembered Tradititons and Lifestyles of Soviet Kyrgyzstan”, Inner Asia, C.12, S.1, 2010, s. 157-175.

FIGGES, Orlando, Karanlıkta Fisıldaşanlar: Stalin Rusya'sında Özel Yaşam, çev. Nurettin Elhüseyni, YKY, İstanbul 2011.

GORBAÇOV, Mihail S., Oktyabr i perestroyka: revolutsia prodoljaetsa, Politizat, Moskova 1987.

GULETTE, David, "Tribalism in Kyrgyzstan Examined”, Central Asia and Caucasus, C.14, S.2, 2002, s. 31-37.

GULLETTE, David, "The Problems of the "Clan" Politics Model of Central Asian Statehood: a Call for Alternative Pathways for Research", E. Kavalski (ed) içinde, Stable Outside, Fragile Inside?: Post-Soviet Statehood in Central Asia, Farnham, Ashgate 2010, s. 5369.

GÜRBÜZ, Yunus Emre, "Demokrasi ve Otoriterlik Sarkacında: Kırgızistan," Bağımsızlıklarının Yirminci Yılında Orta Asya Cumhuriyetleri: Türk Dilli Halklar Türkiye ile İlişkiler, c.I, ed. Ayşegül Aydıngün, Çiğdem Balım, Atatürk Kültür Merkezi (AKM), Ankara 2012, s.133-219.

Volume 12

GÜRBÜZ, Yunus Emre, "Orta Asya'nın Ortasında bir Ada: Kırgızistan”, Hacettepe Üniversitesi Türkiyat Araştırmaları Dergisi, Ankara, Hacettepe Üniversitesi Türkoloji Araştırmaları Enstitüsü, C.15, Güz 2011, s. 419-447.

HERZOG, Werner, André Singer, Meeting Gorbachev, A\&E Networks, New York 2018.

İĞMEN, Ali, Speaking Soviet with an Accent: Culture and Power in Kyrgyzstan, University of Pittsburgh Press, Pittsburgh 2012.

JOLDOSHOV, Altynbek, "Kabilecilik, Bölgecilik ve Etnisite: Kırgız Kimliği Üzerine Çalışmalar", OAKA, C.8, S.15, 2013, s. 101-133.

KUNZE, Thomas, Thomas Vogel, Das Ende des Imperiums: Was aus den Staaten der Sowjetunion wurde, Ch. Links Verlag, Berlin 2015.

MILLER,Chris, The Struggle to Save the Soviet Economy. Mikhail Gorbachev and the Collapse of the USSR, The University of North Carolina Press, Chapel Hill 2016.

NOVE, Alec, Stalinism and After. The Road to Gorbachev,University of Glasgow, London 1988.

SCHATZ, Edward, Modern Clan Politics: the Power of Blood in Kazakhstan and Beyond, University of Washington Press, Seattle 2004.

ZUBOK,Vladislav M. A Failed Empire: The Soviet Union in the Cold War from Stalin to Gorbachev, The University of North Carolina Press, Chapel Hill 2007.

\section{Görüş̧mecilerin Listesi}

[Ad, soyad, görüşmenin yapıldığı yer ve tarih]

Abdıkalık Satiev, Bişkek, Nisan 2007

Abdikapar Omorov, Suuzak, Calal-Abad, Mayıs 2007

Abdıkerim Baktıgulov, Narın, Mayıs 2007

Abdıkerim Kocanazarov, Ala-Kızıl, Bişkek, Nisan 2007

History Studies 
Almunzak Araev, Panfilov, Çüy, Nisan 2007

Asankan Cumakmatov, Bişkek, Nisan 2007

Asankarı Azimov, Narın, Mayıs 2007

Asankul Alimbayev, Kemin, Çüy, Nisan 2007

Ataş Turusbekov, Oş, Mayıs 2007

Baltagul Caparov, Narın, Mayıs 2007

Bermet Asranova (İsayeva), Kara-Tarık, Oş, Mayıs 2007

Bübüra Kıdıraliyeva, Alamüdün, Çüy, Nisan 2007

Bübüsayra Omorova, Beş-Küngöy, Bişkek, Nisan 2007

Bübüyna Oruzbaeva, Isık Göl, Mayıs 2007

Cakşıbayeva Zulayka, Kırgız-Ata, Oş Mayıs 2007

Caparkul Kıdırbaev, Narın, Mayıs 2007

Corobay Bayimbetov, Calal-Abad, Mayıs 2007

Erkegan Canaliyeva, Isık-Köl, Mayıs 2007

Esengul Turdukulav, Cumgal, Narın, Mayıs 2007

Gülbara Düyşenaliyeva, Bişkek, Nisan 2007

Gülsana Aşirova, Calal Abad, Mayıs 2007

Gülzada Cumaşova, Talas, Mayıs 2007

İşenbay Abdırazakov, Bişkek, Nisan 2017

Kadıça Mamırova, Çañgek, Oş Mayıs 2007

Kadir Baybosov, Narın, Mayıs 2007

Kalkanbay Aşımbayev, Isıkköl, Mayıs 2007

Karabay Alakunov, Narın, Mayıs 2007

Katça Orunbaeva, Cañı-Arık, Çüy, Mayıs 2007

Köçkön Saktanov, Oş, Mayıs 2007

Kuseyn İsayev, Bişkek, Nisan 2007

Magrifa Rahimova, Bişkek, Nisan 2007

Mamacali İsayev, Karateyit, Oş, Mayıs 2007

Manap Corobekov, Calal Abad, Mayıs 2007

Manap Kalcigitov, Leylek, Batken, Mayıs 2007

Maripa Düyşönkul, Andalak, Batken Mayıs 2007

Mariya Bayezova, Talas, Mayıs 2007

Mistegül Şarşenkul kızı, Tokmok, Çüy, Nisan 2007

Nurilya Mambetaliyeva, Suusamır, Çüy, Nisan 2007

Orozbek Düyşeev, Talas, Mayıs 2007

Santi Dosbayeva, Karaköl, Calal Abad, Mayıs 2007

Sidıkov Duvana, Narın, Mayıs 2007

Sırgak Sooronkul uulu, Bişkek, Nisan 2007

Süyünbay Eraliyev, Talas, Mayıs 2007

Toktor Turgunbekov, Talas, Mayss 2007 
Toyçu Akbotoev, Çoñ-Alay, Oş Mayıs 2007

Tölögön Kasımbekov, Bişkek, Nisan 2007

Tursun Ayılçieva, Talas, Mayıs 2007

Ubaydulda Ümetaliev, At-Başı, Narın, Mayıs 2007

\section{Metin İçinde Alıntı Yapılan Görüşmeciler}

[Ad, soyad, görüşmenin yapıldığı yer ve tarih]

Abdıkalık Satiev, Bişkek, Nisan 2007.

Almunzak Araev, Panfilov, Çüy, Nisan 2007.

Asankan Cumakmatov, Bişkek, Nisan 2007.

Ataş Turusbekov, Oş, Mayıs 2007.

Bübüra Kıdıraliyeva, Alamüdün, Çüy, Nisan 2007.

Bübüsayra Omorova, Beş-Küngöy, Mayıs 2007.

Corobay Bayimbetov, Calal-Abad, Mayıs 2007.

Gülbara Düyşenaliyeva, Bişkek, Nisan 2007.

İşenbay Abdırazakov, Bişkek, Nisan 2007.

Kadir Baybosov, Narın, Mayıs 2007.

Kalkanbay Aşımbayev, Isıkköl, Mayıs 2007.

Karabay Alakunov, Narın, Mayıs 2007.

Köçkön Saktanov, Alay, Oş, Mayıs 2007.

Volume 12

Mamacali İsayev, Karateyit, Nisan 2007.

Orozbek Düyşeev, Talas, Mayıs 2007.

Toktor Turgunbekov, Talas, Mayss 2007.

Tursun Ayılçieva, Talas, Mayıs 2007.

Ubaydulda Ümetaliev, Narın At-Başı, Mayıs 2007. 